\title{
Usability of Methodology from the USA for Measuring Effect of Corporate Tax on Organizational Form in the Czech Republic Petr Svoboda"
}

\begin{abstract}
:
The goal of this paper is to examine the methodology, used by authors MackieMason and Gordon for measuring effects of corporate tax on business organization form, which is connected to issue of double taxation, in the United States and find out, if the same approach can be applied on business environment in the Czech Republic. Eventually recommend changes for this methodology to be more suitable for this environment taking into account its specific factors.
\end{abstract}

Key words: Double taxation; S-corporation; C-corporation; Czech tax environment; Business organizational form.

JEL classification: $\mathrm{H} 25, \mathrm{H} 32$.

\section{Introduction}

When businessman starts a new business, he must face the question, what kind of organizational form will his company have. The choice of organizational form will influence many aspects of his business including tax issues and therefore the profits of his company. This is a huge decision in the beginning of the firm's operation, but organizational form can be changed also later as the business activity grows or declines.

Organizational form of company can have big influence on the profits, which will owners get from company. The choice of organizational form is affected by both non-tax and tax factors. This article focuses on the tax factors, specifically how much does corporate tax create disincentive to incorporate. Generally speaking, different kind of organizational forms are subjects to different taxing approach. Some organizational forms of business are exposed to double taxation, while other forms are not.

Companies that are double taxed are usually classed as $\mathrm{C}$ corporations (by the United States law). The principle of double taxation of company profit is that company's profit is at first taxed by corporate tax and then, when owners want to take earnings from company, they have to tax these revenues again by personal income tax. One profit is therefore taxed twice.

Petr Svoboda; Institute of business economic and management, Faculty of economics and administration, University of Pardubice, Studentská 95, 53210 Pardubice, Czech Republic, <petr.svoboda@student.upce.cz>. 
Svoboda, P.: Usability of Methodology from the USA for Measuring Effect of Corporate Tax on Organizational Form in the Czech Republic.

On the other hand, companies that are classed as so called S-corporations (by the United States law) don't have to apply corporate tax on their income. The owners of the company have to pay only personal income tax when they take company profit.

Theoretically, with the increase of corporate tax, profitable $\mathrm{C}$ corporations should be switching their forms into $\mathrm{S}$ corporations to avoid double taxation, so their profits would be taxed only by personal income tax, when their owners take profits from company. And conversely, S corporations with losses should face incentive to corporate for gaining advantages of this organizational form.

The goal of this article is to examine the methodology, used by authors MackieMason and Gordon in the United states for measuring effects of corporate taxes on organizational form of the business and determine, if the same methodology could be used to find influence of corporate taxes on organizational form of companies in business environment of the Czech Republic, eventually suggest some changes in this methodology to be applicable.

\section{Current state of knowledge}

The effects of corporate tax (or income taxes in general) on organizational form were examined in the past by many authors. Authors Ayers, Cloid and Robinson (Ayers, Cloid and Robinson, 1996) in their study focused on effects of tax and non-tax factors on organizational form of small businesses in the United States. They concluded that non-tax factors play important role in the selection of the organizational form of small businesses, however, their analysis provided only partial support for hypothesis, that income taxes are important considerations in selection of organizational form. Authors Luna and Murray (Luna and Murray, 2008) examined effects of state taxes on choice of organizational form in the United States. They concluded that both federal and state factors determine the choice of business entity. Results of their analysis suggest that state tax policy does affect business decision-making including choice of organizational form of business. Mackie-Mason and Gordon created two studies about effects of taxation on business organizational form (Mackie-Mason and Gordon, 1991), (MackieMason and Gordon, 1994). In their work they created theoretical model how company decides its organizational form based on tax and non-tax factors. Because this article is based on their study, the model will be described in the chapter bellow. They also made empirical study about effects of corporate tax on choice of organizational form in the United States for data from years 1959-1986. They conclude corporate tax has an effect on the choice of organizational form of business. Another similar empirical study was made by Goolsbee (Goolsbee, 1998) in the United States for data from years 1900-1939. In Czech literature author Hrdý (Hrdý, 2011) focuses on influence of taxes on financial management 
and business decision-making. He mentions organizational form of business can have a huge impact on the amount of profits, which owners will get from company, because of double taxation issue. Authors Karin and Gordon (Karin and Gordon, 2013) conducted study about influence of tax and non-tax factors on the choice of organizational form by closely-held firms in Sweden. They conclude that estimated effect of taxes on the choice of organizational form is much larger than those found in most past studies like study made by MacKie-Mason and Gordon in the United States. Interesting study is also the one made by Carrol (Carrol, 2010) in the United States. This study focuses on subject of harmful effects of double taxation on the United States' economy and business and effects of lower tax rate on dividends enacted in 2003 by the Job and Growth Tax Relief Reconciliation Act of 2003.

\section{Theoretical framework}

This chapter will focus on theoretical model how a firm chose its ideal organizational form creating equilibrium between positive and negative effects of tax and non-tax factors on selected organizational form. In this theoretical model it is simply considered, that a company can choose only between two classes of ownership: C corporation type that is taxed both at corporal and personal level and $\mathrm{S}$ corporation type, that is taxed only on personal level. Also various factors which affect organizational form are simply divided into tax and non-tax factors.

The theoretical model of firm's choice of organizational form was described by authors MacKie-Mason and Gordon (Mackie-Mason and Gordon, 1991), who described the net cost of incorporation by this equation:

$$
\operatorname{COST}=-g\left(1-r_{c}-\left(1-r_{c}\right) r_{e}\right)+I_{x}\left(r_{c}+\left(1-r_{c}\right) r_{e}-r_{n}\right)
$$

Where $g$ means any non-tax factors that make $\mathrm{C}$ corporation form more attractive ( $\mathrm{g}$ can be also negative), $r_{c}$ is corporate tax rate, $r_{e}$ represents implicit personal tax rate per dollar of income to equity, taking as given the division of this income between dividends and capital gains, $r_{n}$ is personal tax rate on ordinary income and $I_{x}$ stands for taxable income of the company.

This equation (1) tells us when it is favourable for company to incorporate. It is when the effects on non-tax factors $(g)$ applied when company chose to incorporate and become $\mathrm{C}$ corporation increase the net profit of company more, than added corporate tax rate $\left(r_{c}\right)$, applied on taxable income $\left(I_{x}\right)$ of $\mathrm{C}$ corporations will decrease net profit. Simply put, we could say, that switching from $\mathrm{S}$ corporation to C corporation is in company's favour only if this equation is true:

$$
\mathrm{g}\left(1-\mathrm{r}_{\mathrm{c}}-\left(1-\mathrm{r}_{\mathrm{c}}\right) \mathrm{r}_{\mathrm{e}}\right)>\mathrm{I}_{\mathrm{x}}\left(\mathrm{r}_{\mathrm{c}}+\left(1-\mathrm{r}_{\mathrm{c}}\right) \mathrm{r}_{\mathrm{e}}-\mathrm{r}_{\mathrm{n}}\right)
$$


Svoboda, P.: Usability of Methodology from the USA for Measuring Effect of Corporate Tax on Organizational Form in the Czech Republic.

The problem with an approach to measure the effects of corporate tax on organizational form of company lies within the left side of equation (2). It is possible to calculate the right side of the equation, but the left side sums up many different non-tax factors which are not easy to measure in money. In their original work MacKie-Mason and Gordon admit that non-tax determinants of organizational form appear to be dominant. MacKie-Mason and Gordon (MackieMason and Gordon, 1991) mention two non-tax factors $(g)$, limited liability and public trading of shares and these factors deserve a closer look because they play a significant role in decision of owners to incorporate, yet it causes problem in methodology approach for measuring effects of corporate tax to organizational form:

- Limited liability. Generally speaking, limited liability is a characteristic of C corporation type of business, where shareholders are protected from some or all of liability for act and debts of company. While partners and unincorporated sole proprietors have unlimited liability. Now it could appear that limited liability is a positive thing, that is reducing risks connected with business, but this is not so easy to determine. Firstly, there are some types of organizational form, such as limited partnership, that are taxed only on personal level, yet still have limited liability, so the businessman can choose this type of corporation to get limited liability, but avoid double taxation. Secondly, the limited liability can make worse the problem of asymmetrical distribution of information between owners and potential creditors, making it more difficult for company to obtain additional capital, which is one of the main reasons, why company chose to incorporate at first place. So effect of this non-tax factor can be positive, as well as negative in some cases.

- Public trading of shares. Public trading of shares offers company access to lower cost equity capital. Also public trading of shares can contribute to solve the principal-agent problem, because manager's compensation is tied to his contribution to an increase of company's value. The problem with this nontax factor is, that some non-corporate companies can have also access to public trading of their shares.

For measuring effects of corporate tax on organizational form, considering that variable $\mathrm{g}$ cannot be properly measured, it is useful to focus only on the right side of the equation (2), which can be actually properly measured. Based on this side of the equation we can create verifiable hypotheses which are:

1. Increase of variables $r_{c}$ and $r_{e}$ from the equation (1) will encourage companies with taxable profits to disincorporate and companies with tax losses to incorporate.

2. Increase in $r_{n}$ from the equation (1) will encourage companies with tax losses to disincorporate and companies with taxable profit to incorporate. 
These hypotheses can be tested using data on time series for aggregate division of companies between corporate and non-corporate organizational forms.

\section{Methodology used for measuring effect of corporate tax on organizational form}

In this chapter specific methodology used by MacKie-Mason and Gordon will be described (Mackie-Mason and Gordon, 1991). This methodology is used to measure effects of taxes on business organizational form in the USA between 1959-1986. They collected various aggregate data about net income, net loss and share of all assets of C corporations, S corporations from Internal Revenue Service (IRS) for their study on the effect of corporate tax on business organizational form in USA. It was important that collected data were divided into profit and loss companies for all organizational form because aggregated net income would be a poor indicator of allocation of economic activities and resources across organizational forms.

The effect of taxes on organizational form of companies was measured by estimating the effect of changes in the average value each year of the relative tax treatment of corporate and non-corporate income. Tax treatment was measured by $r_{c}+\left(1-r_{c}\right) r_{e}-r_{n}$ from the equation (1). The principle of analysis was to test correlation among changes of tax rates $r_{c}, r_{e}, r_{n}$ and a change of share of assets held by $\mathrm{C}$ and $\mathrm{S}$ corporation and change of shares of aggregate gains and losses of $\mathrm{C}$ and $\mathrm{S}$ corporations and find out if there is any relation. Testing the covariation using only corporate tax rate $r_{c}$ would not be sufficient for two reasons. Firstly, corporate tax rate between 1959 and 1986 in the USA almost did not change, so there cannot be created any regression. Secondly, because of the way double taxation of $\mathrm{C}$ corporations is used, it is important to include personal tax rates in calculations. The tax price incentive for allocation of capital across organizational forms depends on personal tax on ordinary income and personal tax on equity as well, as you can be seen in equation (1). Tax rates $r_{c}, r_{e}, r_{n}$ were determined the following way:

- Two crude measures were used for corporate tax rate $r_{c}$. One measure was realized average tax rate as ratio of tax payment to taxable income, because it takes into account progressivity of corporate tax as well as asymmetric loss offset provision. The second measure was highest statutory marginal rate in the given year.

- Two crude measures were also for personal tax rate on ordinary income $r_{n}$. One was the highest statutory marginal personal tax rate in given year. The second one was an estimation of implicit tax rate calculated by Kochin and Parks (Kochins and Parks, 1988) by comparing yields on Treasury and 
Svoboda, P.: Usability of Methodology from the USA for Measuring Effect of Corporate Tax on Organizational Form in the Czech Republic.

municipal bonds which represents a tax rate for those potentially investing in non-corporate businesses.

- Personal tax rate on equity income $r_{e}$ was calculated from this equation:

$$
\mathrm{r}_{\mathrm{e}}=\mathrm{dr}_{\mathrm{n}}+(1-\mathrm{d}) \gamma \alpha \mathrm{r}_{\mathrm{n}}
$$

Where $d$ is nominal income from dividends, $\gamma$ is income from capital gains that are taxable and $\alpha$ is an adjustment for taxable capital gains to capture the benefits from deferring accruing tax liabilities until the asset is sold plus benefits from the capital gains exemptions for some assets held at death.

Four different time series measures of the relative tax price on corporate assets were created based on two different approaches to determine corporate and personal tax rate. Personal tax rate on equity was constructed based on the equation (3). It is not important the exact a value of tax price each year, but changes of this value each year, thus creating a time trend which can be used for regression.

These four-time series, created for years 1959-1986 were tested for correlation with aggregated data about the change of share of assets held by $\mathrm{C}$ and $\mathrm{S}$ corporation and change of aggregate gains and losses of $\mathrm{C}$ and $\mathrm{S}$ corporations between 1959-1986.

Interpretation of the results was following:

- Estimated tax price effect on the fraction of assets held by $\mathrm{C}$ corporations: correlation coefficient was negative, meaning that the higher the tax disadvantage (i.e. higher corporate tax rate) for $\mathrm{C}$ corporations is, the lower fraction of assets held by this type of corporation is.

- Estimated tax price effect on the fraction of gains and losses reported by $\mathrm{C}$ corporations: for deficit $\mathrm{C}$ corporations the correlation coefficient was positive, meaning that increase of tax disadvantage for $\mathrm{C}$ corporations leads to increase of fraction of losses reported by $\mathrm{C}$ corporations, gains are shifted into non-corporal for of business. For gain $\mathrm{C}$ corporations the correlation coefficient was negative, meaning the higher is tax disadvantage, the lower the profit is reported by this type of business.

\section{Applicability of described methodology in the Czech Republic}

In this chapter the applicability of method used by Mackie-Mason and Gordon (Mackie-Mason and Gordon, 1991) for measuring effect of corporate tax on organizational form of business in the Czech Republic will be analysed.

First of all, types of organizational structures of companies and their tax treatments are quite similar in the Czech Republic and the United States, where the original study was made. In the Czech Republic, corporate types of business (public limited company labelled as a.s. and private limited company labelled as s.r.o.) are 
subjects of double taxation in the same manner as in the United States, while noncorporate types of business such as partnership is a subject of only personal income tax (Hrdý, 2011). The one difference in the tax systems in the Czech Republic and the United States is the corporate tax being progressive (IRS, 2003) through the whole examined period between 1959-1986 in the United States while the corporate tax in the Czech Republic is flat from its origin (Kozelský, Jedlička, 2013). From this point of view, it is definitely possible to create a similar study on corporate tax effect on switching between corporate and non-corporate forms of business, flat corporate tax rate having no effect on the approach to calculation, because of the way that corporate tax rate $r_{c}$ was determined as ration of tax payments to taxable income and highest statutory marginal tax rate. Actually a flat tax rate should make calculation more accurate because it applies the same way on all of the brackets of corporate income so instead of taking the highest marginal statutory rate we can simply take corporate tax rate in given year. Also it is worth mentioning that authors of the original study had to deal with problem of corporate tax rate being almost unchanged in examined period, making it impossible to create any regression using just the corporate tax rate. But the situation is different in the Czech Republic. From its origin in 1993 until 2015 the corporate tax rate has changed significantly. The corporate tax rate changed 11 times, ranging from the highest rate $45 \%$ to the lowest rate of 19\% (Kozelský, Jedlička, 2013). This makes it possible to also create regression using just corporate tax rate and comparing it with the share of assets held by $\mathrm{C}$ and $\mathrm{S}$ corporation and change of shares of aggregate gains and losses of $\mathrm{C}$ and $\mathrm{S}$ corporations within the examined period of time. It would still be more beneficial to make regression from original tax treatment $r_{c}+\left(1-r_{c}\right) r_{e}-r_{n}$ described by Mackie-Mason and Gordon, because this tax treatment contains all tax incentives for shifting organizational form. The Czech Republic has similar institution as IRS for obtaining main source of aggregated tax data about $\mathrm{C}$ and $\mathrm{S}$ corporations, which is Financial Administration (Finanční správa, 2014). Aggregated data about C and S corporations such as their values in relevant years or amount of profits or capital could be obtained through The Czech Statistical Office (ČSÚ) or by own data collection and research.

When tax treatment for the Czech Republic is calculated, it is necessary to solve a few issues specific to the Czech Republic tax system. The first issue is that the personal tax is progressive in some years in the Czech Republic in its history. Authors of original study had to find a solution for tax progression as well. This solution is either taking the highest marginal rate in given years or to estimate an average tax rate (if the necessary data can be obtained). The second issue is to determine personal tax rate on equity income in the Czech Republic. In original tax treatment for study in the USA, the personal tax rate on equity income was determined by the following equation: $r_{e}=d r_{n}+(1-d) \gamma \alpha r_{n}$ (explanation of 
Svoboda, P.: Usability of Methodology from the USA for Measuring Effect of Corporate Tax on Organizational Form in the Czech Republic.

variables in previous chapter). This equation could be also used for the Czech Republic but it is necessary to calculate or find the values of $d$ and $\alpha$ differently. Value $d$ (part of nominal income obtained in form of dividends) will be determined by pay out ratio for companies in the Czech Republic. Interesting study that can be helpful in this matter was published by Bena and Hanousek (Bena, Hanousek, 2005), who calculated pay out ratio of different companies in the Czech Republic. Variable $\alpha$ should take into account that shares sold after certain time after being owned are not a subject of taxation. The biggest issue, which needs to be dealt in the future research in this area is to consider including social and health insurance paid from earning of non-corporate type of business into calculations in the methodology used for the Czech Republic. Social and health insurance was not included in the original methodology by Mackie-Mason and Gordon in the United States, but in the Czech Republic social and health insurance could have an important impact on the results. This impact is best demonstrated on a simplified example: Let's assume that there is one public limited company and one partnership company who have the same amount of profit, which is $1,000,000 \mathrm{CZK}$. This profit in case of public limited company will be taxed at first by $19 \%$ corporate tax and then by $15 \%$ income tax, so the net profit for shareholder will be $688,500 \mathrm{CZK}$. This profit is not a subject to social or health insurance. In the case of partnership, the profit will be taxed only by $15 \%$ income tax, so the profit after income tax will be 850,000 CZK. This looks like quite a big difference instead of 688,500 CZK of profit in case of limited public company. But owner of partnership will also have to pay health (13,5\% rate) and social $(29,2 \%$ rate) insurance from half of his profit 1,000,000 CZK. After paying this insurance, they will get net profit of $636,500 \mathrm{CZK}$. So when we include social and health insurance into calculation the net profit of partnership owner is actually lower than net profit of owner of public limited company in this example, meaning the advantage of non-corporate business being taxed only once by income tax is cancelled by duty to pay social and health insurance. From this simple example it is clear that it is necessary to find the way, how to include social and health insurance into original methodology made by Mackie-Mason and Gordon. The solution can be to modify original tax treatment $r_{c}+\left(1-r_{c}\right) r_{e}-r_{n}$ into this form: $r_{c}+\left(1-r_{c}\right) r_{e}-\left(r_{n}+s+h\right)$. Where $s$ is social insurance rate and $h$ is heath insurance rate. This new formula for tax treatment implies that the higher the rates of both insurances are, the more benefical it is to have corporate type of business because profit from this type of business is not subject to social and health insurance.

The problem of social insurance is even more complex, because of existence of maximal assessment basis for paying social insurance in the Czech Republic. This means that the higher the profit of partnership is above this maximal assessment basis, the more preferable single taxation of non-corporate business is. One 
approach to solve this in future analysis could be to divide companies into two profit brackets. One bracket with companies with profits so low, that the duty to pay health and social insurance significantly lowers benefits of single taxation of non-corporate business and second bracket including companies with profit high enough above maximal assessment basis for paying social insurance, that it is beneficial to have a single taxation advantage of non-corporate business. For this high profit bracket, tax treatment formula would be: $r_{c}+\left(1-r_{c}\right) r_{e}-\left(r_{n}+h\right)$. In the Figure 1 bellow the average tax rates of $S$ corporation and $C$ corporation with different amount income are shown. Income tax (15\% tax rate), social insurance $(29,2 \%$ rate), health insurance $(13,5 \%$ rate) and also special tax for income above 48 times the average wage ( $7 \%$ rate) are applied on income of S corporation. Also a minimal assessment basis for paying social and health insurance and a maximal assessment basis for paying social insurance is included. The corporate tax (19\% rate) and income tax (15\% rate) are applied on income of C corporation.

\section{Fig. 1: Average tax rates of $S$ and $C$ corporations with different amounts of income}

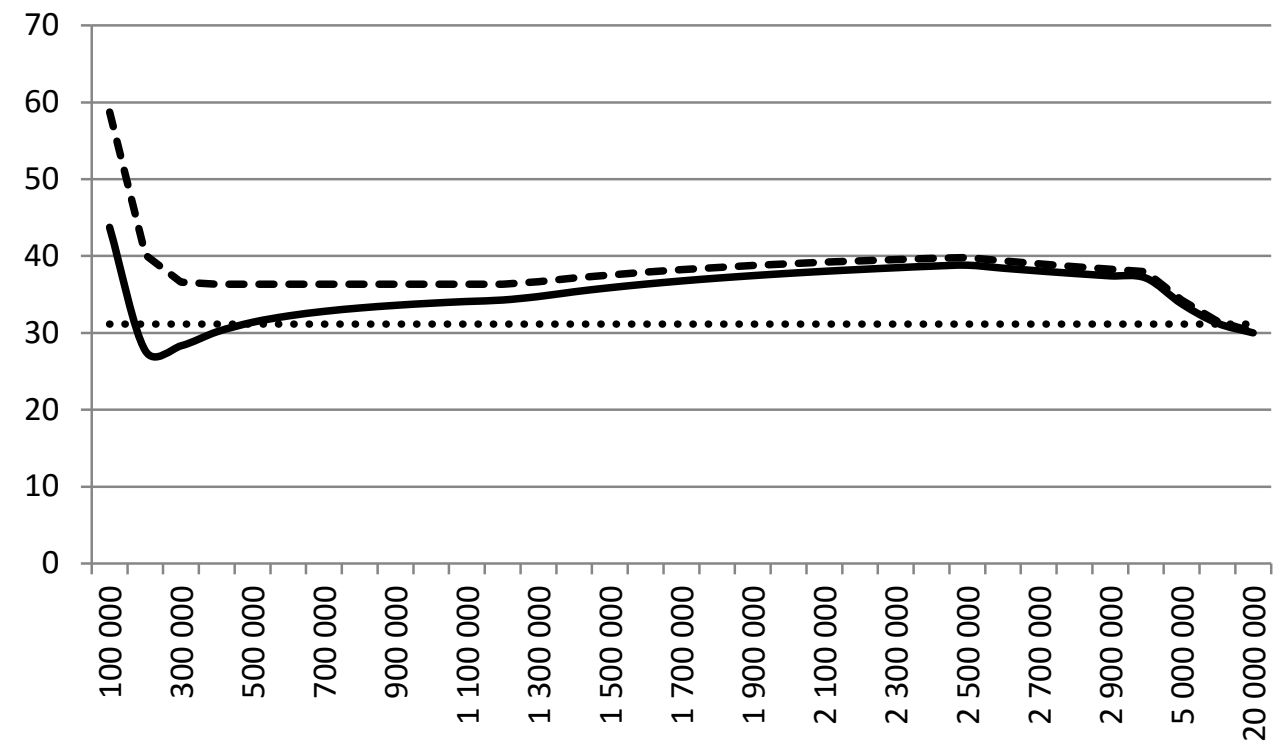

average tax rate for $\mathrm{S}$ corporation with basic tax allowance

...... average tax rate for $\mathrm{C}$ corporation

- - average tax rate for S corporation

Source: Authorial computation. 
Svoboda, P.: Usability of Methodology from the USA for Measuring Effect of Corporate Tax on Organizational Form in the Czech Republic.

Figure 1 shows that average tax rate of $\mathrm{S}$ corporation is lower than $\mathrm{C}$ corporation when income is above 10 million CZK. And with higher income the tax advantage of $\mathrm{S}$ corporation is increasing. If basic tax allowance for owner of $\mathrm{S}$ corporation is included in the computation, then average tax rate of $\mathrm{S}$ corporation is also lower than C corporation when income is between approximately 200,000 CZK and 400,000 CZK.

\section{Conclusion}

The goal of this paper was to examine if the methodology used by authors MackieMason and Gordon for measuring the effects of corporate tax on organizational form in the United States could be used in the Czech Republic. The Czech Republic and the United States are very similar in both tax systems and types of business organizational forms for the purpose of using methodology described above. The issue of double taxation for corporate business also exists in both environments. The interesting note is that while corporate tax in the United States almost did not change during examined period, corporate tax in the Czech Republic had significant variability, which could make results of analysis more significant during its existence.

It will be necessary to solve some difficulties when calculating tax treatment for each year in the Czech Republic. Namely it will be estimating personal tax rate for years, when this rate was progressive in the Czech Republic, finding way to determine personal tax rate on equity income, but most of all, finding a way to include social and health insurance into calculations as these two factors play a huge role in the Czech Republic.

In conclusion, the methodology is applicable in the Czech Republic with some adjustments. Further research in this area could also expand original methodology making the model more-dimensional. Original model is $y=x$ meaning share of assets held by $\mathrm{C}$ corporations/S corporations, gains and losses reported by $\mathrm{C}$ corporations or other statistics of $\mathrm{C}$ and $\mathrm{S}$ corporations (variable $y$ ) is determined by tax treatment (changes or corporate tax rate, personal tax rate on ordinary income and personal tax rate on equity income, variable $x$ ). This model could be expanded for example into this model: $y=x+a+b$, where $y$ and $x$ mean the same as in the previous model, $a$ is variable that takes into account changes of GDP growth in each year and $b$ is a variable that takes into account administrative burden of paying taxes for corporations in each year. 


\section{References}

Ayers, B., Cloyd, C., Robinson, J., 1996. Organizational form and taxes: An empirical analysis of small business. Journal of American Taxation organization 18, 49-67.

Bena, J. and Hanousek, J., 2005. Rent Extraction by Large Shareholders: Evidence Using Dividend Policy in the Czech Republic. Charles University, Center for Economic Research and Graduate Education, Prague. Available from: <http://home.cerge-ei.cz/hanousek/divi01.pdf>. [30 January 2016].

Carrol, R., 2010. The Economic Effects of the Lower Tax Rate on Dividends. Tax foundation 181, 1-12.

Finanční správa, 2014. Daňová statistika. Available from: $<$ http://www.financnisprava.cz/cs/dane-a-pojistne/analyzy-a-statistiky/danovastatistika>. [12 November 2015].

Goolsbee, A., 1998. Taxes, organizational form, and the deadweight loss of the corporate income tax. Journal of Public Economics 69, 143-152.

Gordon, R., Mackie-Mason, J., 1991. Taxes and the choice of organizational form. NBER Working Paper 3781.

Gordon, R., Mackie-Mason, J., 1994. Tax distortions to the choice of organizational form. Journal of Public Economics 55, 279-306.

Hrdý, M., 2011. Vliv daní na finanční řízení a rozhodování podniku. Český finanční a účetní časopis 3. Available from: <www.vse.cz/polek/download. php?.jnl=cfuc\&pdf=124.pdf $>$. [13 June 2014].

IRS, 2003. Corporation Income Tax Brackets and Rates, 1909-2002. Available from: 〈https://www.irs.gov/pub/irs-soi/02corate.pdf〉. [12 November 2015].

IRS, 2015. Internal Revenue System. Department of Treasury. Available from: <https://www.irs.gov/uac/Tax-Stats-2>. [12 November 2015].

Karin, E., Gordon, R., 2013. The choice of organizational form by closely-held firms in Sweden: tax versus non-tax determinants. Oxford journals: Industrial and Corporate Change 1, 219-243.

Kochins, L. A., Parks, R. W., 1988. Was the tax - exempt bond market inefficient or were future expected tax rates negative? Journal of finance 4, 913-931.

Kozelský, T., Jedlička, J., 2013. Korporátní daně v Evropské unii. Česká spořitelna, Praha. Available from: <http://www.csas.cz/static_internet/ cs/Evropska_unie/Specialni_analyzy/Specialni_analyzy/Prilohy/euspa_korporatni _dane_v_eu.pdf>. [12 November 2015].

Luna, L., Murray, M., 2008. Effect of state tax structure on bussiness organizational form. University of Tennessee, Knoxville. 